\title{
Influence Of Joint Television Viewing On Romantic Satisfaction And Family Commitment: A Study Of Spouses In Delta State Secretariat Complex Asaba
}

\author{
Chinenye Nwabueze, Ph.D \\ Department of Mass Communication \\ Chukwuemeka Odumegwu Ojukwu University \\ Anambra State, Nigeria \\ Emmanuel Odishika \\ Department of Mass Communication \\ Novena University, Delta State, Nigeria
}

\begin{abstract}
The subject of this research is the influence of joint television viewing on the romantic satisfaction and family commitment of spouses in Delta State Secretariat Complex, Asaba, Delta state. The study adopted the purposive sampling method also known as judgmental sampling. The instrument of data collection was the interview guide. One hundred and twenty six (126) spouses were purposively selected and studied in this work. All the respondents were individually subjected to an average of $\mathbf{3 0}$ minutes long in-depth interview conducted over a period of three (3) months. The cultivation theory and the uses and gratifications theory served as the guiding theories for the study. The major objective of the study was to assess the influence of joint television viewing of programmes on the romantic satisfaction and family commitment of spouses in the secretariat. The result showed a great correlation between joint television viewing of love related programmes and the romantic satisfaction as well as family commitment of spouses in the secretariat complex. However, this degree of correlation was absent in the case of joint television viewing of other programmes that are not love related. Therefore, the paper recommends, among others, that spouses should selectively expose themselves to love stories that teach selfless love and sacrifice rather than those with default story lines that tend to be acrimonious and divisive of couples.
\end{abstract}

\section{INTRODUCTION}

The wish of a happy married life is a popular refrain that is often chorused by friends and family members during marriage ceremonies in our societies. As our loved ones take marital vows, we commit ourselves to what we believe will be a lasting marriage filled with joy and happiness. This ideal of a long lasting companionate relationship is what we are all searching for (Johnson, 2005). This ideal was captured in Aristotle's philosophy regarding the meaning of life when he stated about 2,400 years ago that people seek happiness and a life filled with "that which is good and lasting” (Dollahite, in Johnson, 2005). Arugu (2014) opins that ordinarily, an ideal marriage will remain united, undivided and unbroken. Unfortunately, present day trends in marriages in our societies seem to indicate that these ideals are fast becoming utopian. As Johnson (2005) described it, "we seem to live in an era where the commitment to our marital relationships is slowly diminishing. Divorce, once a difficult ruling to obtain, can now be justified by simply citing 'irreconcilable differences,' and where divorce cases used to be in the minority, now many married individuals seem to have experienced at least one divorce". 
Obi, in Arugu (2014) defines marriage as a union between a man and a woman that lasts the duration of the man's life and the woman's life. Mbiti (2007) avers that it is a religious and ontological duty for everyone to get married. Despite this significance, our societies are now faced with situations where marriages fail and couples cannot tolerate living together (Arugu, 2014), an experience that is simply known as divorce. According to Grath, in Arugu (ibid) divorce is a legal or customary decree that a marriage is dissolved. In other words, divorce is a permanent separation of married people as a result of unexpected marriage outcome. Mbiti (2007) calls divorce a delicate accident in marital relationship. Hoffman and Duncan, in Segrin and Nabi (2002) report that the failure of marriages in America continues to be a pervasive problem. VanDanBergh, in Johnson (2005) laments the high divorce rates and the collapse of traditional marriage life in America. Cherlin and Furstenberg (2000) found that over 11\% American children were living with one biological parent and one step parent in 1992. They estimated that a fourth (ie 25\%) of American children will live with a step parent before reaching the age of sixteen.

Back home in Nigeria and Africa, the sordid picture of broken marriages is not different from that of America. In the traditional African society of old, marriage divorce was seldom permitted and the rate of divorce was generally low. But today, marriage divorce is a growing social ill in our societies (Arugu, 2014). Given the soaring figures of divorce rates in our societies, scholars are beginning to pay more attention to marital satisfaction and the factors that affect it. Adegoke (2010) blames the high rate of divorce in Nigeria on urbanisation and industrialization. Other factors responsible for divorce are said to be childlessness (Mbiti, 2007); alcoholism (Adegoke, 2010); immaturity (Komblum, 2001; Reiners 2003; Rhyme, 2010; Jones, 2000; white \& Booth, 2001); Religious affiliation (Jones, 2000; Tilson and Larson, 2000) and others. Segrin and Nabi (2002) believe that one explanation for the high divorce rates in our society is the idealistic expectation with which many people enter into marriage. The media have also been cited as the source of or major contributor to these expectations. Signorielli, in Segrin and Nabi (2002) argued more specifically that television may be the single most common and pervasive source of conceptions and action related to marriage and intimate personal relationships for large segments of the population. Ward, in Segrin \& Nabi (2002) corroborates this position by saying that the role of the mass media, specifically television, has received increasing attention regarding its portrayal of love and romance, presenting numerous verbal and visual examples of dating, intimacy, sex and marriage. To Johnson (2005) the mass media seems obsessed with love and marriage through media reports, talk shows and reality television just as people seek ways to be happy in marriage. Incidentally, a number of leading marriage and relationship education programmes encourage couples to value and understand the benefits of spending time together as it is an important condition for a flourishing relationship (Fein, 2009). Obviously, joint television viewing by spouses offers an opportunity for such a condition stipulated above. He goes further to affirm that the time spent together is necessary for communicating, maintaining intimacy, providing support and sharing activities that deepen relationship satisfaction and commitment. Hence, this study aims at examining the influence of joint television viewing on the attainment of much desired family commitment and romantic satisfaction in marriages.

\section{Statement of Problem}

The evidence of research accounts by scholars points to a disturbing gap between the ideals and expectations of marriages and the disappointing outcome of marriage divorces experienced by couples in recent times (Johnson, 2005; Arugu, 2014; Mbiti, 2007). While VanDanBerghe, in Johnson (2005) laments the high divorce rates and the collapse of traditional marriage life in America; Arugu (2014) regrets the fact that whereas marriage divorce was seldom permitted and generally low in African societies of old, it has now become 
a growing social ill. Adegoke (2010) blames the high rate of divorce in Nigeria on urbanization and industrialization. Among many other reasons advanced for the failure of marriages by scholars is the idealistic expectations with which people enter into marriage (Segrin and Nabi, 2002). Studies have blamed the media, specifically the television, for inducing the unrealistic portrayals that have become inimical to the success of marriages, Signorelli, in Segrin \& Nabi, 2002; Johnson, 2005). On the other hand, a number of leading marriage and relationship education programmes encourage couples to value and understand the benefits of spending time together (Fein, 2009), Such as joint television viewing, as an important condition for a flourishing relationship. This research aims at establishing the veracity or otherwise of the claims that such love portrayals on television create idealistic expectations that eventually affect marriages negatively. This is especially so because of the far reaching implications of the subject on the wellbeing or otherwise of marriages and the society at large. To Harden (2014), the effects of divorce on society are drastic because, as he observed, the greatest cause of juvenile crime is a broken home According to Arugu (2014), the family is the bedrock of the community. Families are of paramount importance to the Nigerian society because they are considered to be the basic unit of society. He submits that, the future of Nigeria as a country depends so much on successful marriages and parenting.

Therefore, the findings of this research will help validate or debunk the claims by several scholars (Segrin \& Nabi,2002;Hetsroni, 2012; Johnson, 2005) that unrealistic, idealistic and romanticized portrayals of marriage by television affect family commitment and romantic satisfaction in marriages. If this is indeed true, then the recommendations of this study will help in obviating such consequences in the interest of the Nigerian society. This is one of the problems of this research. Besides, the researcher also discovered that there is a dearth of local studies on the subject. Hence, the other problem of this research is the advancement of valid findings that will help fill the existing gap in knowledge especially in relation to the role of joint television viewing in the determination of romantic satisfaction and family commitment in marriages.

\section{Objectives of the study}

The specific objectives of this study are:

1. To ascertain the nature of the spouse's joint television viewing activity.

2. To find out the types of programmes they watch together with their spouses.

3. To assess the influence of joint television viewing on the romantic satisfaction of the spouses.

4. To assess the influence of joint television viewing on the family commitment of the spouses.

5. To establish the relationship between joint television viewing of love theme programmes and the romantic satisfaction of the spouses.

6. To establish the relationship between joint television viewing of love theme programmes and the family commitment of the spouses.

\section{Research Questions}

1. What is the nature of the spouses' joint television viewing activity?

2. What are the types of programmes the spouses watch together with their spouses?

3. Does joint television viewing influence the romantic satisfaction of the spouses?

4. Does joint television viewing influence the family commitment of the spouses?

5. Is there a relationship between joint television viewing of love theme programmes and the romantic satisfaction of the spouses?

6. Is there a relationship between joint television viewing of love theme programmes and the family commitment of the spouses? 


\section{THEORETICAL FRAMEWORK}

The cultivation theory and the uses and gratifications theory will form the basis for this study.

\section{Uses and Gratifications Theory}

According to Nwodu (2006) uses and gratifications theory presupposes that media audiences are active audience members who deliberately expose themselves to a given content to gratify their needs. Nwabueze (2014) affirms that the basic tenets of this theory are that people expose themselves to media contents based on the needs and gratifications they derive from such contents. To Agbanu (2013), the theory is rooted on the assumption that reception of the contents of a mass mediated message takes place in anticipation of some rewards.

Herzog, Lazardfeld's colleague, is often credited as the originator of the uses and gratifications theory. The article, Motivation and Gratifications of Daily Serial Listeners which was written in 1944 became the first published research work to profoundly view the concept of media gratifications (Baran \& Davis, 2009). The uses and gratifications theory, also known as needs theory, is preoccupied with the why answer to media use. As Okunna (1999) put it, it is the functional use of the media that the theory is concerned about. The theory is worried about what people do with the media. It assumes that members of the audience are not passive but rather, are actively involved in interpreting and integrating the media into their lives. The approach suggests that people use the media to fulfill specific gratifications. Simply put, one of the basic assumptions of the uses and gratifications theory is that audience members have certain needs that are satisfied using both non-media and media sources... (Dominick, 2009). Therein lies the relevance of this theory to the study.

Katz et al., (1974) cited in Baran \& Davis (2006) listed five elements or basic assumptions of the uses and gratifications theory as:

- The audience is conceived as active with goal oriented mass media use.

- Much initiative in linking gratification and media choice lies with the audience members.

- The media compete with other sources for need satisfaction.

- People have enough awareness of their own media use, interest and motives to be able to give researchers an accurate picture of that use.

- Value judgment of the content should be suspended.

Furthermore, the researchers grouped goals for media use into five uses namely:

- Be informed or educated

- Identify with characters of the situation in the media environment.

- Simple entertainment

- Enhance social interaction

- Escape from the stress of daily life.

However, recent developments in media studies have updated Uses and Gratifications Theory (UGT) to include Gratifications Sought (GS) versus Gratifications Obtained (GO). If GO is greater than GS then there will be more audience satisfaction. Incidentally, audiences' GS are not always the reality of their GO (LaRose et al., 2001). This discrepancy between GS and GO is important in the uses and gratifications research.

\section{The Cultivation Theory}

Cultivation theory is one of the long term media effect theories developed by George Gerbner in 1973. The central message of the theory was that viewing television gradually leads to the adoption of beliefs about the nature of the social world which conform to the stereotyped, 
distorted and very selective view of reality as portrayed in a systematic way in television fiction and news (McQuail, 2005). Gerbner and his colleagues went further to propose that, compared to light television viewers, heavy television viewers are more likely to perceive the world in ways that more closely mirror reality as presented on television than more objective measures of social reality, regardless of the specific programmes or genres viewed (Gerbner \& Gross, in Segrin \& Nabi, 2002).

In the context of marital expectations, cultivation theory suggests that in portraying idealized images of marriage, the media may be cultivating unrealistic beliefs about what marriage should be (Segrin \& Nabi, 2002). In the view of Morgan and Shanahan (2010), heavy television viewing may lead the viewers to accept estimations and views that are represented on the screen with unrealistic frequency compared to their real occurrence. The cumulative effect of this, according to Gerbner et al (2002) is the internalization of norms, beliefs and evaluations of social reality that are routinely depicted on television. Again, Morgan and Shanahan (2010) assert that cultivation can be interpreted as having occurred when a significant relationship exists between the amount of time devoted habitually to television viewing and the adoption of views and assessments that are often presented. Given this background, it remains to be seen whether the findings of this study will prove the case of the cultivation theorists.

\section{Operationalising Key Concepts.}

Joint Television Viewing: This is the coming together of married men and women that work in Delta State Secretariat to watch common programmes on television with their spouses at the same time, space and location.

Family: A married man or woman working in the Delta state secretariat complex and his or her spouse.

General Programmes: Other programmes on television that are not love related.

Love theme programmes: These are programmes on television that feature stories with love as their central theme.

Romantic Satisfaction: A feeling of happiness from the physical attention, care and love of a spouse usually expressed in kind words, self-disclosure, kissing, cuddling, caressing, lovemaking etc.

Family commitment: This is the dogged determination to stay all the way with one's spouse in a marital relationship.

Spouse: A husband or a wife working in the Delta State secretariat complex.

\section{LITERATURE REVIEW}

\section{Family Commitment and Romantic Satisfaction: Key Elements of Marital Satisfaction}

In recent years, scholars have paid more attention to marital satisfaction. The rational for studying marital satisfaction stems from its centrality in individual and family wellbeing, from the benefits that occur in society when strong marriages are formed and maintained and from the need to develop interventions for marital distress and divorce as they have become more prevalent (Castro-Martin and Bumpass; Stack and Eshleman) in (Johnson, 2005). This position is shared by Guerrero, Anderson and Afifi (2011) in their affirmation that forming personal romantic relationships is a central, innate and biological component of human behaviour. Two 
of the key elements that are necessary for the attainment of marital relationship satisfaction are family commitment and romantic satisfaction.

According to Rusbult and Buunk, cited in Miller and Tedder (2014), relationship satisfaction is defined as an interpersonal evaluation of the positivity feelings for one's partner and attraction to the relationship commitment and romantic satisfaction. To Sternberg and Hojjat (1997) relationship satisfaction is the overall subjective evaluation of the romantic relationship. Kelly and Thibaut, cited in Reizer and Hetsroni (2014) aver that romantic satisfaction is a result of the fulfillment of positive expectations, assuming that people are satisfied if they evaluate the relationship as meeting or exceeding a set of internal standards of a "good" relationship and do not perceive any other relationship as meeting those standards better. Evidence from researches indicate that those who see their partners as closely matching their ideal standards report higher quality relationships (Simpson, Fletcher and Campbell, 2001). On the other hand, Rusbult and Buunk, in Reizer and Hetsroni (2014) define relationship commitment as the intention and desire to maintain the relationship in the long term. Le \& Agnew (2003) enthuses that commitment predicts staying together and plays a key role in the success or failure of dating and marital relationship. Much more than that, commitment contributes to maintaining the relationship and its positive functioning by promoting positive behaviours (Arriaga \& Agnew, 2001; Rhoades, Stanley \& Markman, 2010). In the view of this researcher, family commitment can be defined as the deliberate injection of positive energy into a marital relationship with a spouse in order to ensure its sustainability.

\section{Joint Television Viewing and Marital Satisfaction}

There have been research findings establishing a relationship between heavy television viewing and overly optimistic romantic expectations (Segrin \& Nabi, 2002; Hetsronic, 2012) as well as idealistic views of marriage and courtship (Holmes, 2007; Holmes and Johnson, 2011). In the words of Huston, Niehuis and Smith (2001) individuals who hold unrealistic romantic beliefs tend to encounter disillusionment and disappointment in later phases of their relationships when they realize that sustaining these romantic ideals is not feasible. A study from Albion College on 390 married couples found that the more an individual believed in the television portrayals of romance, the less likely they were to be committed to their relationship (Osborn, 2012). The study also found that the more an individual believed in the television portrayals of romance, the more their relationship costs were, that is, loss of personal freedom, loss of time or painful consciousness of their partners unattractive qualities. In other words, heavy television watchers, joint or individual, stand the risk of jeopardizing the status of their romantic relationships.

In another study, taken from the perspective of maintenance behavior, it was observed that maintenance behaviours (i.e. positivity, understanding, self disclosure, assurances, relationship talks etc) play an important role in sustaining relational states, especially within committed romantic relationship (Andregg, Dale and Fox, 2014). Also researches have shown that comparisons with ideal media portrayals of relationships are likely to lead to a negative evaluation of one's own relationship, and as a consequence, lower satisfaction with the relationship (Holmes \& Johnson, 2011).

\section{Portrayal of Idealized and Romanticised Notions of Marriage on Television}

Demo and Granong, cited in Segrin and Nabi (2002) have argued that one of the most insidious factors undermining marital satisfaction and longevity is that individuals enter into marriage with unrealistic, idealistic and romanticized notions about marriage. Whereas similar researches have confirmed the fact that unrealistic beliefs are deleterious to marital satisfaction and stability (Segrin and Nabi, 2002), it is not very clear as to where their beliefs 
take their roots from. In this regard, the media have been cited as one of the sources or a major contributor to the sprouting of these idealistic expectations about marriage. Illouz (1998), observed from a series of studies that subjects themselves often claimed that media representations were responsible for their views of romance. Signorielli, in Segrin and Nabi (2002) argued more specially that television may be the single most common and pervasive source of conceptions and action related to marriage and intimate personal relationships for large segments of the population. In a corroboration account, Ward, also in, Segrin \& Nabi (2002) affirms that the mass media, specifically television, has received increasing attention regarding its portrayal of love and romance. Infact, researchers have found that belief in television portrayal of romance is a strong prediction of people's expectations of relationships and marriage (Osborn, 2012; Segrin \& Nabi, 2002). Hetsroni (2012) is in agreement. He remarks that excessive media consumption and especially heavy television viewing are related to overly optimistic romantic expectations. Reizer and Hetsroni (2014) submit that, indeed, there is abundant evidence that heavy television viewing correlates with idealistic, unrealistic and sometimes even old fashioned beliefs concerning romance that are typical of popular programming.

\section{Joint Television Viewing as a Home-Based Leisure Activity}

Couples' marital satisfaction plays a vital role in the preservation of the family. And since families are the fundamental unit of society, it follows that stronger marriages lead to stronger families and strengthened societies (proclamation, 1995, in Johnson, 2005). One of the factors that have been found to affect marital satisfaction is couple leisure. One of the ways joint couple leisure affects marital relationship is by creating couple bonding. Orthner and Mancini, in Johnson (2005) identified three types of couple leisure activity patterns. They are; individual, parallel and joint couple leisure patterns. By definition, individual leisure refers to leisure that is done without one's spouse; parallel couple leisure refers to individual participation in the same activity at the same time, such as watching television with one's spouse with little or no communication or interaction between the couples; and joint leisure activity is a situation where couples participate together with a high level of interaction. From the foregoing definitions, it becomes clear that for a couple joint leisure activity to impact on the couple's relationship satisfaction, such activity must be highly communicative and interactive between the couples as is evident in the joint leisure activity pattern.

Still on couple leisure, studies have also suggested the core and balance model of family leisure functioning (Zabriskie, 2000) as an explanation for how family leisure involvement influences families. Where core couple leisure is depicted by joint participation in activities that are common, regular and usually home-based; balance couple leisure is depicted by joint participation in activities that are less common, less frequent and often out of the ordinary experience. However, much as studies have shown that families who regularly participate in both core and balanced family leisure activities are likely to function better and have greater family satisfaction than those who do not (Johnson, 2005), the interest of this study is limited to the examination of joint television viewing as a home-based activity within the category of core and joint couple leisure.

\section{Joint Television Viewing, Couple Time and Marital Satisfaction}

In analyzing the place of couple leisure in marital satisfaction, Johnson (2005) had observed that it is still not clear as to whether it is the kinds and amount of couple leisure involvement, or the amount of time spent together, that contributes to marital satisfaction. Hence, there have been many studies on the relationship between the amount of time couples spend together and the quality of marital relationship. Hill, in Fein (2009) found that higher amounts of shared leisure were associated with a strongly reduced probability of splitting up in analysis 
of 280 married couples interviewed in the 1975-1981 Time Use Longitudinal Panel Study in America. A similar effect was found for greater amounts of time spent as a couple alone in analyses of 3,476 married couples in the national survey of families and households (Presser, 2000). Other studies have also established the fact that leisure time has increased slightly among couples (Aquiar \& Hurst, 2006) and that rather than declining; the amount of time couples spend together has actually increased slightly in recent decades (Fisher et al., 2006). Also, results from studies have shown that economically disadvantaged couples spend slightly more time together than non-disadvantaged ones, and that they spend more of the time they are together in leisure activities, largely watching television (Fein, 2009). Still drawing from the data provided by the 1975-1981 panel study, Kingston and nock, in Fein (2009) reported that, for dual earner married couples and single earner married couples, watching television accounted for the largest share of couple time (about an hour a day). In sum, Fein (2009) submits that time spent together is necessary for communicating, maintaining intimacy, providing support and sharing activities that deepen relationship satisfaction and commitment. Thus, in general, relationship quality should increase as couples spend more time together. This is the interest of this study, especially as it relates to point television viewing.

\section{Joint Television Viewing and Sex on Television: Implications for Marital Satisfaction}

According to Eidelson \& Epstein, in Segrin \& Nabi, (2002), two dominant themes emerge from the conceptualization of idealistic marital expectations. The dominant theme that partners who really care about each other should have complete understanding of their partners' needs and preferences; and the theme that sexual relations will be perfect. The later theme captures the issue of sex, a very important aspect of romance in marriage. It brings to the fore the portrayal of exaggerated sexual prowess on television and the expectations of unusually passionate and compatible physical intimacy which, if not met can constitute a potential threat to marriages. Unfortunately, television programmes are as preoccupied with the portrayals of idealized relationships as they are with depictions of sex. Studies have shown a link between sex portrayal and the quality of marriage relationship. For instance, sexual content seen on television has been linked to beliefs and expectations about sexual experiences in married romantic relationship (Aubrey et al. 2003). Further researches have also shown that elaborate illustrations of romantic relationships in television programmes also affect the physical, emotional and sexual expectations of married couples (Eggermont, 2004).

\section{Marriage in Nigeria: A Contextual Analysis}

This review will be done in the context of this seminar topic and against the background of the socio-cultural changes that have beset the concept of marriage in traditional Africa. Obi, cited in Arugu (2014) defines marriage as a union between a man and a woman that lasts the duration of the man's life and the woman's life, as well as a social structure that promotes an association and agreement between two families. Stark, in Amadi and Amadi (2014) identifies four primary functions of the family to include: sexual relationships, economic cooperation among members, reproduction and the educational function, which is the socialization of the children into the larger society. With the arrival of the children, the family keeps expanding and the society keeps growing. This is especially so with the typical African society where marriage is seen basically as a process of procreation. A good marriage guarantees a peaceful and joyful atmosphere in the home which is most suitable for bringing up healthy and happy children. According to Okon (2010) research has shown that children who grow up in healthy and happy environments are more likely to excel in school and in all other aspects of life including their own marital life.

Ordinarily, an ideal marriage is united, undivided and unbroken. Unfortunately, in spite of the significance of marriage, every society is faced with situations in which marriage fails and the 
couples cannot tolerate living together, a situation that leads to divorce (Arugu, 2014). The prevalence of divorce in marriages in our present day societies gives cause for concern. We seem to live in an era where the commitment to our marital relationships is slowly diminishing. Divorce, once a difficult ruling to obtain can now be justified by simply citing irreconcilable differences, and where divorce cases used to be in the minority, now many married individuals seem to have experienced at least one divorce. Nigeria is not without its fair share of broken marriages. In the traditional African society of old, divorce was seldom permitted and the rate of divorce was generally low. But today, divorce is a growing social ill in our society (Arugu, 2014). Divorce, which used to be an aberration in African societies, has since become a new way of life with us. Mbiti (2007) calls divorce a delicate accident in marital relationships. Adegoke (2010) blames the high divorce rate in Nigeria on urbanization and industrialization. Other reasons such as childlessness, alcoholism, immaturity etc have been adduced by scholars as factors responsible for the growing rate of divorce in Nigeria. Curiously, none of these studies on causes of divorce in Nigeria have blamed media consumption, especially television viewing, despite the findings of research that unrealistic portrayals of romance on television correlates strongly with problems in marriages. Therefore, it is hoped that this study will assess correctly the influence of joint television viewing on family commitment, romantic satisfaction and overall marital satisfaction of couples in Nigeria.

\section{The Delta State New Secretariat Complex, Asaba}

The Delta State Civil service secretariat complex is comprised of two complexes: the old secretariat complex and the new secretariat complex. The new secretariat complex was discretionally chosen by the researcher for this study. The new secretariat complex is located on Maryam Babangida way, off Okpanam road in the heart of the state capital, Asaba. There are a total of seven different departments in the complex comprising the ministries of economic planning, education, health, finance, sports development, bureau for special duties and the office of the Accountant General of the state. The total staff population of the new secretariat is 1,902. Out of this number, a total of 1,303 are married, while 599 are still single. A closer look at the married population of the secretariat staff shows that 684 are married men, while 619 are married women, and since the study was targeted at married, co-habiting men and women who engage in joint television viewing with their spouses, a total of 126 respondents who met these criteria were purposively chosen and studied.

\section{METHOD OF STUDY}

The study adopted the purposive sampling method also known as judgmental sampling. The merit of purposive sampling stems from the fact that the researchers skill and fore-knowledge of sample characteristics to a large extent, guide researchers choice of samples (Nwodu, 2006). The method imbues in the researcher the prerogative of judgment in selecting his respondents based on certain predetermined criteria that will serve the purpose of the research. In this case, the predetermined criteria for choosing the respondents are three-fold: one, the respondents must be married couples; two, they must be co-habiting, and not correspondent, married couples and three, they must be couples that routinely engage in joint television viewing in terms of sameness of time, location and space. After a long and tortuous process of elimination of those that did not meet the specific criteria, the study was narrowed down to 126 qualified respondents comprising 69 married men and 57 married women.

Information was obtained from the respondents using face to face in depth interview sessions. The interview guide was used for these interviews. It was divided into sections A, with questions on demographic details; $\mathrm{B}$, questions on spouses joint television viewing details; $\mathrm{C}$, questions on joint television viewing and romantic satisfaction; and D, questions on Joint television viewing and family commitment. The Delta State New Secretariat Complex at 
Maryam Babangida way, off Okpanam road in Asaba is the area of Study. Out of the 1,902 workers in the secretariat complex, 126 workers were purposively selected for this study. The choice of the new secretariat complex for the study was done in exercise of the researcher's discretion.

\section{DATA PRESENTATION AND ANALYSIS}

The responses given to the questions in the interview guide by the 126 purposively sampled respondents constitute the data for this study. The responses given at the interview sessions are, in part, graphically presented in tabular form and simple percentages for ease of comprehension; and the other part is presented by using the explanation building technique.

Table 1 - Demographic composition of respondents

\begin{tabular}{|l|l|l|l|}
\hline S/N & ITEM & FREQUENCY & PERCENTAGE \\
\hline 1. & Gender & & \\
\hline & Male & 69 & 54.8 \\
\hline & Female & 57 & 45.2 \\
\hline 2. & Age (in years) & & \\
\hline & Below 25 & 06 & 4.8 \\
\hline & $26-35$ & 42 & 33.3 \\
\hline & $36-45$ & 54 & 42.9 \\
\hline & 46 and above & 24 & 19 \\
\hline 3. & Age of marriage & & \\
\hline & $1-5 y r s$ & 42 & 33.3 \\
\hline & $6-10 y r s$ & 45 & 35.8 \\
\hline & $11-15 y r s$ & 21 & 16.7 \\
\hline & $16-20 y r s$ & 09 & 7.1 \\
\hline & 21 and above & 09 & 7.1 \\
\hline 4. & Educational Qualification & & \\
\hline & FSLC & - & - \\
\hline & O/L & - & - \\
\hline & NCE/ND/HND & 42 & 33.3 \\
\hline & B.Sc/M.Sc/Ph.D & 84 & 66.7 \\
\hline
\end{tabular}

Table 1 shows a sex distribution of male respondents (54.8\%) and female respondents (45.2\%). It also shows that majority of the respondents $(42.9 \%)$ are between the age range of 36-45 years. Also, there is indication that majority of the respondents are highly educated with most of them (66.7\%) having a minimum of Bachelor's degree; and 33.3\% representing those with NCE, OND and HND. It was zero percent for first school leaving and ordinary level certificates.

On age of marriage, it shows that majority of them have been married for between 6-10years (35.8\%); 1-5years (33.3\%), respectively. Others are 11-15years (16.7\%);16-20 years (7.1\%); 21 and above years of marriage $(7.1 \%)$.

\section{In-depth Interview}

The researcher used the in-depth interview method to elicit more expansive responses from the respondents, especially with regards to the questions in the interview guide that have to do with joint television viewing and how it influences their romantic satisfaction and family commitment. The explanation building technique was used to further explicate the responses for better understanding. 


\section{Nature of Joint Television Viewing Activity}

Majority of the respondents often engage in joint television viewing of programmes with their spouses. In this category are those who said they observe this routine on a daily basis, with the least of them exercising this routine at least five times a week. On the other hand are those who said that they are not often engage in this joint television viewing exercise. For those in this category, they are only involved in this activity between 2-3 times a week. Some others within this category said they only indulge in joint television viewing of programmes during weekends alone. Altogether, all the respondents engage in this activity but with varying degrees of frequency. On location and space of joint television viewing activity, majority of the respondents said they watch programmes together in their living rooms. The number of those who said that they watch the programmes in their bedroom was far lower in comparison to those that use their living rooms. In between are those who stated that they use both the living room and the bedroom as their moods dictate. The distribution of the programmes jointly watched by the respondents and their spouses are captured in this descending order of popularity: soaps, news, sports, religious programmes and documentaries respectively. When the respondents were asked specifically if they jointly view love related programmes, an overwhelming number of respondents answered in the affirmative while a few said they do not. On the frequency of exposure to love story programmes, most of the respondents said they do this quite often. Another good number of them said they do so, but no so often. Contrariwise, a few of the respondents maintained that they do not see love story programmes with their spouses at all.

\section{Influence of Joint Television of general Programmes Viewing on Romantic Satisfaction and Family Commitment}

Some of the questions in the interview guide sought to know how joint television of general programmes, influence the romantic satisfaction of the respondents in their marriage. Majority of the respondents believed that joint television viewing does not have any influence on their romantic satisfaction. Most of them actually dismissed such a possibility with a wave of the hand. This feeling was aptly captured by one of the respondents in these words: "the things I see on television are inconsequential to my feelings in my marriage". On the other hand, there were some respondents who expressed the opinion that their romantic satisfaction were positively and negatively influenced by joint television viewing of programmes. On the positive side, one respondent said, 'joint television viewing influenced my husband and I positively because I learnt to understand him by watching what he likes and it brought us closer together". Another respondent complained that joint television viewing affects his romantic relationship with his wife negatively because "she does not usually have much interest in news and football. At such times, she feels ignored and becomes upset so much so that it ruins our day or night". One of the respondents put it rather bluntly thus: "watching some of these programmes like news about happenings in Nigeria kills ones romantic desires"

On the influence of joint television viewing on family commitment, an overwhelming majority of the respondents said that joint television viewing does not in any way influence their commitment to their spouses. As one respondent put it, "my marriage to my husband is beyond the influence of television. It is for better or worse"

\section{Influence of Joint Television Viewing of Love Related Programmes on Romantic Satisfaction and Family Commitment}

The study showed a strong correlation between joint television viewing of love related progammes and romantic satisfaction among the respondents. Most of them were of the opinion that joint television viewing of love related programme influenced their romantic satisfaction. Some of the programmes cited by the respondents include the Zee world series 
such as Twist of Fate, Silver lining, Young Dreams; Telemundo series such as Passion for Revenge, How to Love, Love Alone and others in the African Magic and Super Story series. According to one of the respondents, "specific love programmes influence us positively and leads to increased sexual activity". Another respondent observed that "after watching some of the programmes, body chemistry changes and leads to romance and sexual creativity with my husband". These statements reflect the position of most respondents to the effect that joint television viewing of love programmes prompts intimacy and enhanced sexual activity with their spouses. However, there were some who did not share this opinion. To them, joint viewing of love related programmes create emotional tension, separation and distancing between them and their spouses. Infact, for some respondents, the influence of watching the portrayal of perfect love relationships on television was so adverse to their romantic relationship that the couple had to take a drastic decision to opt for religious programmes on television. The man said, "my wife and I used to be heavy watchers of love programmes like "Telemundo". But we later realized that, rather than bond us, the strange cultural attributes of these love stories that were alien to our culture here, was threatening to tear my wife and I apart. So, to save our marriage we opted for religious programmes on TV". Another respondent blamed the altercations that arise between couples from watching love themes on what he calls "the default lines of the stories". He complained that the story lines in most of the so-called love themes breed distrust and suspicion among couples, thereby driving a wedge between them. He recommended classical story lines such as the one in 'titanic' for couples who are in search of romantic satisfaction and family commitment in their marriages. On the effect of portrayals of perfect couples on their romantic satisfaction, most of the respondents said they learn from such models to improve in their marital romance. Again, there were some dissenters on the positive influence of the portrayals of perfect couples. One of the respondent's views captures this feeling inadequate thus: "the perfect portrayals create tension in my marriage. They make my husband feel inadequate".

On the influence of love programmes and the portrayals of perfect couples on their family commitment, virtually all the respondents insisted that there is no correlation between these variables and their commitment to their marriages. While admitting that such portrayals actually reveal the gaps and failings in their marriages, they submit that such feelings do not translate to a lack of commitment to their family. Rather, they admit that such feelings increase their resilience, resolve and commitment to make their marriages work. Others chose to dismiss the portrayals of perfect couples with a feeling of incredulity. To them, such portrayals are works of fiction and the players are merely earning a living. Hence, it should not be allowed to affect their family commitment. Some of the respondents had the following to say about love programmes and perfect portrayals of couples; "...it encourages me to remain in my marriage with the belief that one day, the wind of happiness will bow into my marriage again". Another said, "the perfect couples strengthen my desire to stay in my marriage and whatever is negative I discard because I know it is based on fiction". One other respondent blurted out saying, "I don't connect what I see on television with my marriage, I watch for fun and relaxation".

\section{FINDINGS}

The findings from the data analysed show that:

- All the respondents engage in joint television viewing but with variegated degrees of frequency. Majority of them often engage in the routine of joint television viewing of programmes with their spouses while the others do so not as often.

- The most watched programme was soaps followed by news, sports, documentaries and religious programmes in that order. 
- Most of the respondents engage in joint television viewing with their spouses in the living room.

- There is a weak correlation between joint television viewing of general programmes and the romantic satisfaction as well as family commitment of the spouses.

- The romantic satisfaction and family commitment of majority of the respondents were positively influenced by joint television viewing of love related programmes.

\section{DISCUSSION OF FINDINGS}

The findings of the study regarding the nature of joint television viewing activity shows that majority of the respondents often engage in the routine of watching television programmes together with their spouses. This finding is in conformity with the position of leading marriage and relationship education programmes that couples should spend time together in order to enjoy a flourishing relationship (Fein, 2009). It also shows that soaps were the most watched programme by the respondents. What is more, the majority of respondents engage in the joint television viewing acidity in their sitting rooms. In all, the frequency of joint television viewing activity, the choice of what to watch and where to watch the programmes characterize the nature of the respondents joint television viewing behavior.

On objectives 3 and 4, the finding that there is a weak correlation between joint television viewing of general programmes and romantic satisfaction echoes the position of earlier studies on this subject. A study of 390 marriage couples from Albion College had shown that the status of a romantic relationship could be in jeopardy if the couple or an individual in the relationship are frequent television watchers (Osborn, 2012). This was the point of one of the respondents who admitted that in the course of watching news or football, he ignores his wife in a way that upsets her and ruins their day or night as the case may be.

The findings of objectives 5 and 6 indicate that the watching of love related programmes positively influenced romantic satisfaction and family commitment of the spouses. This finding is completely at variance with the position of earlier studies that idealistic portrayals of romance on television jeopardizes the status of romantic relationships (Segrin and Nabi, 2002; Hestsroni, 2012; Holmes and Johnson, 2011). The findings of this study do not support this position at all. Rather, the findings are consistent with the recommendation of leading marriage and relationship education programmes that couples should spend time together in other to enjoy a flourishing relationship (Fein, 2009). And whereas, spending time together watching other programmes did not achieve it, the choice of watching love related programmes correlated positively with romantic satisfaction and family commitment of the couples as the findings of the study indicate. Finally, it is instructive that majority of the respondents watch soaps more than other programmes and were rewarded for so doing with romantic satisfaction and family commitment. This is consistent with the position of the uses and gratifications theory that media audiences are active audience members who deliberately expose themselves to given media content to gratify their needs (Nwodu, 2006).

\section{CONCLUSION AND RECOMMENDATIONS}

The wish of a happy married life defines the expectations of man and society in legitimate search for the good life. It is therefore a tragedy of human history that marriage, which used to be a guarantee for the building of a happy and healthy society, is bedeviled by the woeful tale of divorce and broken homes. Among many other factors, the media have been fingered as one of the promoters of the increasing rate of divorce cases through the portrayal of unrealistic romantic beliefs that tend to cause disillusionment and disappointment for believing couples in the late phases of their relationships (Huston, Niehuis and Smith, 2001). Whereas, the findings of this study are in agreement with earlier studies that joint viewing of general programmes 
negates relationship satisfaction in marriages, this is not the case with the joint viewing of love genres. In fact, the findings of this study contradict earlier findings on this subject by showing a strong correlation between joint television viewing of love related programmes and the romantic satisfaction and family commitment of spouses. However, in order to consolidate on the gains of the positive influence of joint television viewing of love genres on spousal romantic satisfaction and family commitment, the paper recommends as follows:

- One, that spouses should be selective of the story lines of the love related programmes that they are exposed to on television. They should opt for love stories that teach true love and sacrifice in preference for those with default story lines that tend to be acrimonious and divisive of couples.

- Again, especially for individual joint viewership, couples should guard against addiction to programmes that would potentially distract them from their primary responsibility of giving attention to their spouses.

- Thirdly, spouses should be mindful of cultivating the negative messages on television that could prove inimical to their romantic satisfaction and family commitment.

- Finally, the researcher recommends further studies on the subject to determine the influence of cultural variability (Fein, 2009) on the outcomes of studies on joint television viewing of spouses with western cultural background and those of the disparate African cultural background.

\section{References}

Adegoke, T.G. (2010) Socio-Cultural Factors as Determinants of Divorce Rates Among Women of Reproductive Age in Ibadan Metropolis, Kamla-Raj Study, Tribes Tribals; (8) 2:107-114

Agbanu, V.N (2013) Mass Communication: Introduction Techniques, Issues. Enugu: Rhyce Kerex Publishers.

Amadi, U.P.N. \& Amadi, F.N.C. (2014) Marital Crisis in the Nigerian Society: Mediterranean Journal of Social Sciences. 5(26): 133-143.

Andregg, C, Dale, k. \& Fox, J (2014) Media Portrayals of Romantic Relationship Maintenance: A Content Analysis of Relational Maintenance Behavioours on Prime Time Television. Mass Communication and Society, 17 (5): 733 753.

Arriaga, X.B. \& Agnew, C.R. (2001) Being Committed: Affective, Cognitive and Conative Component of Relationship Commitment. Personality and Social Psychology Bulletin, 27, 1190-1203.

Arugu, O.L (2014) Social Indicators and Effects of Marriage Divorce in African Societies. The Business and Management Reviews, 4 (4): 374-383.

Aubrey, J.S., Harrison, K., Kramer, L. \& Mellin, J. (2003) Variety Versus Timing: Gender Differences in Married Couples Sexual Expectations as Predicted by Exposure to Sexually Oriented Television.

Baran, S.J \& Davis, D.K (2006) Mass Communication Theory: Foundations, Present and future, Australia: Thomson Wadsworth.

Baran, S.J. \& Davis, D.K. (2009). Mass Communication Theory: Foundation, Present and Future (5th Ed.) Boston. M.A.: Wadsworth Cengage Learning.

Cherlin, A.J. \& Furstenberg, F. (2000) Step Families in the US: A Reconsideration. In: John Horgan(ed): Annual Review of Sociology, Palo Alto, Calf: Annual Reviews, 349-381.

Dominick, R.J. (2009) The Dynamics of Mass Communication: Media in the Digital Age, (10 ${ }^{\text {th }}$ Ed), New York: McGraw Hill Companies Inc.

Eggermont, S. (2004) Television Viewing, Perceived Similarity, and Adolescents' Expectations of a Romantic Partner.

Fein, D.J. (2009) Spending Time Together: Time Use Estimates for Economically Advantaged and Disadvantaged Marriage Couples in the United States.

Fisher, K. Eggerton, M, Gershuny, J.I. \& Robinson, J. (2006) Gender Convergence in the American Heritage Time Use Study (AHTUS). Institute For Social and Economic Research, Working Paper 2006-25. 82, 1-33. 
Gerbner, G., Gross, L., Morgan, M., Signorielli, N. \& Shanahan, (2002) Growing Up With Television: Cultivation Processes. In J. Bryants \& D. Zillman (Eds.), Media Effects: Advances in Theory and Research. Mahwah, N.J: Lawrence Erlbaum. 43-67.

Guerrero, L.K, Anderson, P.A, \& Afifi, W.A (2011) Close Encounters: Communication in Relationships (3 ${ }^{\text {rd }}$ ed.) Los Angeles: Sage.

Harden, J.A. (2004) Divorce; The Real Presence Association, Inc.

Hetsroni, A. (2012) Association Between Television Viewing and Love Styles: An Interpretation using Cultivation Theory. Psychology Reports 110, 35- 50.

Holmes, B.M \& Johnson, K.R (2011) Where Fantasy Meets Reality: Media Exposure, Relationship Beliefs and Standards and the Moderating Effect of a Current Relationship. In: E.P Lamont (ED) Social Psychology. New Research New York: Nova Science. 117-134

Holmes, B.M (2007) In search of my "One and Only": Romance Oriented Media and Beliefs in Romantic Relationship Destiny. Electronic Journal of Communication, 17, 3-4

Huston, T.L, Niehuis, S., \& Smith, S.E (2001) The Early Marital Roots of Conjugal Distress and Divorce. Current Directions in Psychological Science, 10(4), 116-119

Illouz, E. (1998) The Lost Innocence of Love: Romance as a Postmodern Condition. Theory, culture and Society, 161-186.

Johnson, H.A (2005) The Contribution of Couple Leisure Involvement, Leisure Time and Leisure Satisfaction to Marital Satisfaction.

Jones, G. (2000) Modernization and Divorce: Contrasting Trends in Islamic South West Asia and the West. Population and Development Review 23(1):94-114

Komblum, E. (2001) Marriage and Divorce. Sociology in a Changing World. Orlando: Harcourt Brace and Company. LaRose, R., Dana, M. \& Mathew, S.E, (2001) Understanding Internet Usage: A Social Cognitive Approach to Uses and Gratifications (PDF) Social Science Computer Review 19(4): 395-413.

Le, B; \& Agnew, C.R. (2003) Commitment and its Theorized Determinants: A Meta -Analysis of the Investment Model. Personal Relationships, 10, 37-57

Mbiti, J.S. (2007) African Religions and Philosophy; London; Cassal and Ollier

McQuail, D. (2005) McQuail's Mass Communication Theory (5th Ed.) London: Sage Publications.

Morgan, M. \& Shanahan, J. (2010) The State of Cultivation. Journal of Broadcasting and Electronic Media, 54, 337355.

Nwabueze, C.L. (2014) Introduction to Mass Communication. Media Ecology in the Global Village. Owerri: Topshelve Publishers.

Nwodu, C.L (2006) Research in Communication and Other Behavioral Sciences: Principles, Methods and Issues. Enugu: Rhyce Kerex Publishers

Nzekwe, B. (2007) African Marriage and Social Change. London: Frank Cass \& Co. Ltd.

Okon, I.E. (2010) How to Make Your Marriage Work: Daily Sun Newspaper. Tuesday, May 25: 19.

Okunna, S.C. (1999). Introduction to Mass Communication. Enugu: New Generation Books.

Osborn, J.L. (2012) When TV and Marriage Meet: A Social Exchange Analysis of the Impact of Television Viewing on Marital Satisfaction and Commitment. Mass Communication and Society, 2012; 15 (5): 739-757.

Presser, H.B. (2000) Non standard Work Schedules and Marital Instability. Journal of Marriage and the Family, 62: 93-110.

Reiners, D. (2007) Parental Divorce and wellbeing of Children-A Meta Analysis; Psychological Bulletin 110 (1): 2634.

Reizer, A. \& Hetsroni (2014) Media Exposure and Romantic Relationship Quality: A Slippery Slope? Psychological Report: Relationship and Communications 114, (1): 231-249.

Rhoades, G.K; Stanley, S.M; \& Markman, H.J. (2010) Should I Stay? Or Should I Go? Predicting, Dating Relationship Stability from Four Aspects of Commitment. Journal of Family Psychology, 24: 543-550

Rhyme, M. (2010) Preparing for Marriage and Social Change. London: Longman \& Todd. 
Rusbult, C.E. \& Buunk, B.P. (1993) Commitment Process in Close Relationships: an Interdependence Analysis. Journal of Social and Personal Relationships, 10, 175-204.

Segrin, C. \& Nabi, R.L (2013) Does Television Viewing Cultivate Unrealistic Expectations about Marriage? Journal of communication, June 2002, 52 (2): 247-263

Sternberg, R.J. \& Hojjat, M. (1997) Satisfaction in Close Relationships. New York: Guilford Press.

Tilson, J. \& Larson G.R. (2000) Divorce and Separation, Social Work and Social Welfare: An Introduction. (2nd ed). New York: West Publishing Company.

White, L.A. \& Booth, V. (2001) Children and Marital Disruption. American Journal of Sociology, 96: 930-953.

Wimmer, R.D. \& Dominick, J.R. (2000) Mass Media Research: An Introduction. Wadsworth.

Zabriskie, R. (2000) An Examination of Family and Leisure Behaviours Among Families with Middle Aged School Children. Unpublished Dissertation. Indiana University, Bloomington, IN.

Zhekwo, Y.K. (2009) Defining the New Testament Logic on Divorce and Remarriage in a Pluralistic Context. London: Pickard Publications. 